This is the accepted version of the article published by Brill in Journal of Religion in Africa Vol. 46 (2-3), 251-287. Published version available at:

http://booksandjournals.brillonline.com/content/iournals/10.1163/15700666-12340083

Accepted version downloaded from SOAS Research Online: http://eprints.soas.ac.uk/23958/

\title{
Masculinities, new forms of religion and the production of social order in Kaduna city, Nigeria ${ }^{1}$
}

\section{Colette Harris}

Department of Development Studies, SOAS, University of London, Thornhaugh Street, London WC1H OXG, UK

Colette.harris@soas.ac.uk

Word Count: 14,900

\begin{abstract}
From the late 1970s when serious economic woes hit Nigerians in general and the inhabitants of Kaduna in particular, the latter began to seek explanations for the ills that beset their country and support to deal with them. Some found this in new religious movements, both Christian and Muslim, that rejected former sects/denominations as religiously and ethically unacceptable and focused on more modern, individualistic lifestyles as well as providing some measure of material support, explanations and solutions based in the supernatural for the ills the population was suffering. The situation sparked fear of social chaos, partly owing to men's uneasiness at the threat of losing their dominance over wives and offspring along with their control of economic resources. The new religious movements support male superiority while offering greater space for women, provided they keep to their assigned places. These movements thus combine material and social support with the spiritual.
\end{abstract}

\section{Keywords}

Masculinities, gender, reform Islam, charismatic Christianity, northern Nigeria

\section{Introduction}

This paper explores how new forms of religion have been used by inhabitants of Kaduna, ${ }^{2}$ a city in the middle-belt region of northern Nigeria, capital of the state of that name, to support their adaptation to the socio-economic changes of the last few decades and, in particular, how this has aided the maintenance of social order, in tandem with the preservation of current ideals of masculinity, with its symbiotic relationship with religion.

Nigeria's economy is dominated almost entirely by petroleum, in relation to both exports and government revenues, making the country largely a rentier state (Falola and Heaton 2008). As such it has succumbed to the so-called Dutch disease, whereby selling large quantities of natural resources in this case oil - increases the value of the currency, making it cheaper to import goods than to 
produce them domestically and pricing exports out of the market. This has made it more profitable for elites to manipulate the political system in order to capture a share of the oil revenues than to establish their own enterprises or even to provide the infrastructure to make it economically viable for others to do so. The result has been high unemployment levels, especially in the north (Teal 2014).

Poverty rates in Kaduna city have risen enough to threaten the fabric of society, exacerbated since early 2000 by episodes of sometimes quite major violence. While this is usually termed sectarian, since religious affiliation is the crucial element in delineating sides and recent decades have seen considerable faith-based militancy (Falola 1998), resentments arising from competition over oil revenues and the differential access to political power by the various ethnic groups have acted as catalysts for hostilities (Harris 2013).

This has been exacerbated by the struggle to maintain a decent lifestyle resulting from the dearth of basic infrastructure - constant electricity, running water, good roads, schools, and medical establishments. This has made the operation of all sizes of business prohibitively expensive, and thus kept even informal employment low. Successive national governments have attempted to claim the moral high ground, to legitimise themselves through being seen to uphold positive values, in part by enforcing specific notions of decency (Marshall 2009: 103ff). Recent examples include an abortive bill that attempted to legislate for tight control over women's dress and behaviour ${ }^{3}$ and the antihomosexuality bill signed into law in 2014. It has been suggested that the northern states introduced shari'a law starting in 1999 for the same reason. Thus, rather than improving material conditions, governments have preferred to focus attention on potential threats to the social order, most especially those relating to the preservation of 'traditional' and/or religiously sanctioned gender performances (cf. Tamale 2013).

Since the 1970s, many inhabitants of Kaduna have abandoned the older Muslim Sufi and Christian missionary orders in favour of more recently founded religious establishments with messages more in line with current circumstances and enhanced capacity to satisfy both spiritual and material needs. These establishments provide support for the preservation of social stability, including by bolstering the position of men and upholding current ideals of masculinity.

In this paper I suggest this has been inspired by the new ways offered by these establishments of developing the spiritual self as well as by explanations for, and some level of protection from, the malign forces feared to be the cause of the wider problems in Nigerian society (Marshall 2009). They also provide material support for the poorest in their congregations, while legitimising and institutionalising existing notions of masculine superiority, albeit with a contemporary twist, and simultaneously granting some level of recognition to women, producing a seemingly win-win 
situation. Thus, I argue, religion and 'traditional' masculine authority have been brought together to provide the bedrock for social stability in Kaduna today.

The paper starts by expounding the fieldwork methodology on which it is based before presenting the conceptual framework, describing the setting of Kaduna and explaining relevant issues concerning religion and masculinity there. Finally, it analyses the contribution of the newer religious institutions to preserving social order and thus helping to ward off chaos.

\section{Methodology}

The data I draw upon come from accounts of missionary work in Africa and its effects (e.g. Labode 1993; Oyěwùmí 1997; Peel 1993, Prevost 2010), contemporary studies of the new religious movements especially Kane (2003), from which much of the background to Izala is taken, and Marshall (2009), and fieldwork in Kaduna carried out between 2007 and 2011 in conjunction with a series of grass-roots community education projects in different neighbourhoods. ${ }^{4}$ The social analyses carried out by participants in these projects included gender as a significant element, the starting point being their identification of the norms of masculinity and femininity in their own communities. This formed the basis for discussions on how the norms of masculinity pressured men into certain kinds of often negative activities, such as domestic violence or street fighting. The participants comprised adult women aged between 20 and 60, most with little if any schooling, and youths aged between 15 and 35 , the latter mainly but not solely male, all of whom had some schooling, and most of whom were either still in or had completed secondary school. Altogether, over 60 youths, forty Muslims and twenty Christians, and 80 women, about thirty of whom were Christians, participated in the projects. ${ }^{5}$ The Christians belonged to Anglican, Baptist and several different Pentecostal churches; while some Muslims belonged to Sufi orders, most followed the reform Izala movement, of which Kaduna is an important centre (Ben Amara 2011).

I also worked with Anglican, Baptist and Pentecostal ministers as well as Izala Imams and helped form a committee of Muslim and Christian religious leaders, with the aim of improving mutual understanding and collectively seeking ways of addressing both the socio-economic difficulties of their congregants and the inter-religious hostility that has resulted in tensions all too often being released through violence.

My approach is ethnographic, and I rarely carry out formal interviews, drawing for my data on discussions held during the education sessions, informal conversations with participants and the fathers of some project youths, as well as my encounters with religious and community leaders, both Christian and Muslim. I make no claims for the generalisability of the data presented in this paper to 
the over 1.5 million inhabitants of Kaduna city (Bununu et al 2015) but rather describe the situation from the perspective of those with whom I worked there.

\section{Conceptual Framework}

\section{Gender}

Gender is an analytical concept, not simply standing for women or even males and females but rather denoting power relations emanating from what formerly were categorised as a biomedically-based masculine superiority and feminine inferiority, translated into two clearly bounded identity positions (Oyěwùmí 1997: 32ff). The salience of gender is the pressure experienced by both sexes to live up to sets of norms established in their own families and communities; thus, it concerns power at the collective and not just the individual level (Harris 2004), based on maledominated structures that form an important element of governmentality. The norms must be performed since it is by their behaviour that people are recognised as meeting expectations. This is not to suggest the norms are mechanically reproduced but rather that individuals accommodate, negotiate and manage them as best they can. They are aided by what I have termed 'gender masks' modes of self-presentation that can be used to mimic gendered expectations in order to present an appearance of conformity, irrespective of reality (Harris 2004).

Gender is culturally and historically situated. The very notion of norms, along with the particular form taken by them in distinct cultural groups, is socio-politically constructed over time. The set of norms described in this paper has spread widely as a result of (neo)colonialism and globalising capitalism, the media and other influences, including religion, that have produced strong similarities in the construction of the norms over much of the globe. Among the most crucial and persistent elements are the association of breadwinning with masculinity and domesticity with femininity, notions that developed largely in industrialising England in the nineteenth century (Rose 1986), although they feed into interpretations from elsewhere, such as Islam (Imam 1994).

It has been suggested that prior to Christianisation and colonisation, in Sub-Saharan Africa, the lineage was viewed as more important than the individual (Oyěwùmí 1997; Shaw 2002). Moreover, among the Yoruba of south-western Nigeria, for instance, 'social identity was relational and was not essentialized' by being attached to specific bodies (Oyěwùmí 1997: xiii, 143). If all this is so, gender as defined above was an anachronistic concept in Sub-Saharan Africa and indeed the evidence on human relationships prior to cultural contact with the west would appear to substantiate this (Saidi 2010).

This does not mean male and female were undifferentiated. Historical research reveals both a sexual division of labour and culturally-based sets of appropriate behaviour patterns males and 
females were expected to conform to. However, these were not differentially valued as they were in Europe (Amadiume 1987; Nzegwu 2006; Oyěwùmí 1997).

Power relations were structured along lineage lines, with age and/or seniority playing an important part. Women were valued for both their reproductive and their productive roles. However, today to a varying extent depending on cultural setting, in public discourse at least, the influence of (neo)colonialism and Christianisation has meant women are likely to be deemed inferior (Tamale 2013). Thus, while masculinity and femininity as currently constructed in Nigerian society are considered traditional, implying they derive from antiquity, in fact much of this was forged over the colonial and post-colonial periods, making this tradition relatively recent (Oyěwùmí 1997).

\section{Religion versus rituals}

We tend to assume all cultural groupings had something that can be labelled religion since all had some form of relationship with the supernatural. In so doing we fail to interrogate the term religion and consider its scope. Talal Asad insists 'there cannot be a definition of religion which is universally viable because and to the extent that the effects of these processes are historically produced, reproduced and transformed' (1983: 238). Moreover, the very act of seeking a universal definition is suspect since it implies it will be based on Christian thought, which is unlikely to do justice to entities deriving from other cultures. Each setting needs to be studied from its own perspective (Asad 2001).

There has been in Africa a tendency to buy into European notions of the superiority of monotheism and, in an attempt to refute suggestions of inferiority, to claim this for African 'religions', suggesting they contain similar elements to Christianity (cf. Mbiti 1969, 1970). The Acholi scholar Okot $p^{\prime}$ Bitek strongly criticised this on the grounds that it was a distortion of African culture. His book on his own setting insists the Acholi have no gods and their relationship with the supernatural focuses on propitiation not worship ( $p^{\prime}$ Bitek 1971), thus coming closer to a cult than a religion (cf. Peel 2000).

The aim of the propitiation is to prevent disturbances of the material and/or social order (for instance, by illness or other misfortunes) and restore stability in the here and now, not to lay up merit for an afterlife ( $p^{\prime}$ Bitek 1971; Peel 1993). This is not peculiar to the Acholi but applies to other African cultures too, including the Gbagyi or Gwari peoples of central Nigeria, whose land originally included the area currently occupied by Kaduna city (Adedayo and Sanda 2011).

The Hausa is the largest Muslim group in northern Nigeria. They continue to practise bori rituals, supposedly derived from the customs of unconverted Hausa or Maguzawa (Danfulani 1999). Research in central Nigeria suggests bori practitioners see this as complementary to Islam, insisting Allah created both the spirits that possess them and the ills they seek to cure. Bori continues to 
flourish among some Nigerian Muslims mainly as a form of traditional healing often used by those too poor to afford to consult biomedical practitioners or where allopathic treatments have not worked, but also as a form of crisis management (Andersson 2002).

The disturbances referred to above are often said to be caused by negative witchcraft or sorcery, which have historically been combated through the use of appropriate rituals, deriving from local cultures rather than world religions. For this reason Africans use different terminology for the two. The Acholi, for instance, use the Swahili loan word dini for Christianity and Islam as opposed to their local word for rituals ( $p^{\prime}$ Bitek 1971). John Peel makes the same claim for the Nigerian Yoruba, stating that while they participated in specific local cults, these were deemed integral to their way of life and thus not conceptualised as 'bounded entities' in their own right. They only 'recognize[d] themselves as having "a religion" when they adopt[ed] Islam or Christianity', since 'in the traditional cultures of western Africa, "religion" did not exist as an indigenous category, but was introduced by missionaries and taken up ... by anthropologists to refer to certain cultural and behavioural aspects of the whole community's functioning,' even though these 'customs of the country', including orisa, were ontologically distinct from religion (Peel 1993: 89, 2000: 88-90). This does not exclude crossfertilisation between the two nor does it suggest the rituals/cults were or have ever been static (Shaw 2002: 51, 77).

The same claim is made for the knunu of the Gbagyi (Adedayo and Sanda 2011). Supposedly, for them one reason for religious conversion was to add an additional layer of protection from evil spirits. It might also have presented an opportunity to broaden this protection out from the local to a larger and thus more powerful community. However, even after conversion, traditional rituals continued to be practised, since prayer and other religious acts provided insufficient support to counter everyday negative forces. Most early conversions of the Gbagyi were to Islam - that is, to Sufism - no doubt facilitated by the similarity between some of the practices associated with the local orders and traditional rituals, including rainmaking and anti-witchcraft ceremonies (Adedayo and Sanda 2011; Andersson 2002; Kane 2003).

The Christian missionary orders were categorically opposed to the concepts of the occult behind the rituals, seeing them as the devil's work. Those proselytising among the Gbagyi thus refused to allow their converts to continue practising the rituals but without offering a substitute that might counter supernaturally caused ills. Nor did Christianity seem useful for evoking good spirits to provide adequate rainfall, or protection against illnesses, pests and diseases. Therefore, this religion only gradually took hold among the Gbagyi and knunu practices continued when circumstances required support of a kind unavailable from the missionary churches (Adedayo and Sanda 2011). 
Consequently, although Muslim bori practitioners see their religion as compatible with their rituals and orisa and knunu are also practised alongside religion, they are viewed as occupying distinct spaces. Hence I refrain from conflating them, reserving the term religion for Christianity and Islam, and the terms cults and rituals to refer to various aspects of traditional African practices related to the supernatural. This is not intended to imply their inferiority but rather to distinguish the two analytically. I make no claims regarding modernity either, since both religions and the cults/rituals are historically bounded and thus inseparable from the particular time and place under study.

Their conceptual separation does not make them incompatible. Some elements of the rituals were absorbed into Sufi practice, as stated above. In the hope of increasing their appeal, several mainline churches have deliberately adopted certain ritualistic elements (Larkin and Meyer 2006; Marshall 2009), while many neo-Pentecostals explain misfortune as an effect of malign spirits that only their particular church can overcome (Maxwell 1998).

A further important distinction between religions and the cults and rituals is that the former are deeply implicated in the construction of gender norms. Although men and women frequently play different roles within traditional cults and rituals, these do not regulate gendered behaviour in the same way.. This may go some way to explain the fact that women are sometimes said to use traditional rituals to gain power denied them by religion (Danfulani 1999: 433).

\section{The setting 6}

The British Protectorate of Nigeria was formed in 1914 by combining the Protectorates of northern and southern Nigeria. The former region is dominated by Hausa and Fulani. The latter consists of the south east, where the majority group is Igbo and mainly Catholic, and the south west, where the majority cultural grouping is Yoruba, around a third of whom have converted to Islam, the rest to Christianity (Falola and Heaton 2008).

In 1960, when Nigeria gained independence, the south had long been economically dominant, largely because of its many schools, enabling it to deploy an educated population to occupy administrative and industrial positions; to compensate, the British allocated political power to the north. This institutionalised the north-south divide, conceptualised along ethno-religious lines created by British colonial officials that set the tone for its subsequent political history and prevented it from developing into a united nation-state (Kazah-Toure 2002).

This has been a consequence of the original regional divisions along with the colonial practice of creating hard ethnic boundaries and spatially separating local from incoming populations. The country has been subdivided several times, currently consisting of a federation of 36 states, inhabited by some 250 cultural groupings. Each state may designate specific groups as 'indigenes', all others 
being labelled 'settlers', irrespective of their actual length of time in the region. Settlers are excluded from state government employment and from equal opportunities for tertiary education; they have limited access to other amenities, such as land and university scholarships. This has effectively barred significant portions of the population from inclusive citizenship rights and contributed significantly to community violence (Harris 2013; Kraxberger 2005).

Built in 1912 on land historically populated by the Gbagyi, Kaduna was designed by the British to function as the capital of the then Protectorate of Northern Nigeria. The British assumed the Gbagyi would not mind ceding the land since they had not fully settled it and they were angry at complaints regarding its appropriation. Consequently, not only did the Gbagyi receive no compensation, their claims were never even acknowledged, the British granting rulership rights solely to the Fulani Emir of Zaria. To this day these issues continue to fuel resentment; they have been a significant element in the episodes of sectarian violence that have plagued the city (Harris 2013).

The Gbagyi living in and around Kaduna city south are now mostly Christian, those to the north Muslim (Adedayo and Sanda 2011; Gandu 2011). The remainder of the city's population are Hausa-Fulani Muslims, the largest population group in northwestern Nigeria, and members of smaller groups from southern Kaduna state, as well as Igbo, Yoruba and other ethnicities from southern Nigeria. For the past few decades, the population of the city, as also of the state, has been relatively equally divided between the two religions (Harris 2013).

\section{Economic relations}

Oil was discovered in the Niger Delta in the late 1950s and became particularly important in the 1970 s as a result of the OPEC price hikes that greatly increased the revenues from international sales, boosting the federal budget from three billion dollars in the early 1970 s to some forty-five billion in 1980. This set Nigeria awash with money, much of which went to elites, who initiated a frenzy of importation of status-giving commodities that continued well into the 1980s, long after the rest of the population had been affected by austerity measures owing to the falls in global oil prices that started in 1981, accompanied by state mismanagement and corruption (Watts 1990: 38). The country as a whole had benefited little from the 1970s boom that had provided only minimal upgrading of urban infrastructures and almost totally neglected rural areas so agricultural production dropped drastically, from over 50 percent of GDP in 1970 to around 20 percent a decade later, while its share of exports reduced from more than 60 percent to just over two percent. As a consequence, rural employment fell from over 80 percent in the 1960 s to around 50 percent in the 1980s, accompanied by a decline in real wages. This heightened rural poverty, greatly increasing rural-urban migration (Kane 2003: 43ff). 
Formal employment opportunities were scarce. In the mid-1950s the International Labour Organisation's estimates gave a national average of some 3.6 percent of adult men in waged employment in Nigeria. No more than two percent of waged workers were women, so this category was essentially male. In fact, during the colonial period since an important channel through which the British insisted on their superiority was the breadwinner norm complementing the domesticated femininity of their wives, Nigerian men were inspired to claim their own rights to a breadwinner identity and thus to a family wage. The colonial state, meanwhile, continued to operate based on the contradictory ideology that Nigerian men did not need as high wages as the British because their wives contributed significantly to household finances while making this as difficult as possible by denying women waged employment, on the grounds their place was in the home. The effect was to keep pay low while creating a masculinist ideology whereby men were expected to use their income to support the family but women were allowed to hold on to their own earnings except in cases of extreme family need (Lindsay 2007).

After independence, the number of men working in formal waged labour remained low. In 1975 it was estimated at 7.8 percent (Lindsay 2007) and it has barely grown since - in 2006 fewer than 10 percent of the adult population were formally employed. Today, an additional almost 25 percent of the urban adult population is self-employed with some 25 percent of adults and over 50 percent of youths unemployed. The vast majority of the self-employed work in the informal sector, mostly doing odd jobs, day labouring and other low skilled and insecure work, not running the small enterprises the World Bank lauds as the future of the global economy. Incomes are variable but for most remain low, to the point that some of the least skilled apparently see little point in bothering to work at all as it does little to raise either their status (see below) or their income. Moreover, since 2000, agricultural family employment has been the only category to have registered a significant rise, the implication being that secondary and tertiary education are not paying dividends in the shape of improved employment/income opportunities. Both university and high-school graduates lack appropriate skills due to the significant falls in standards of the respective institutions (Teal 2014).

It has become increasingly difficult for lower-skilled men anywhere in Nigeria to earn a decent living, one that truly allows them to provide for their family's needs. In the north, where Kaduna is situated, the overall economy is doing considerably worse than the national average, with a corresponding effect on earning opportunities. The oil boom had seen Kaduna prosper as the centre of economic and political power in northern Nigeria, as well as of the textile industry. The fall in oil prices of the early 1980s greatly reduced government funding; this hit Kaduna hard and significantly reduced formal employment levels, leaving many men unable to support their families. Women had to attempt to fill the resultant spending gap (Coles 1991). After 1986 these economic woes were 
exacerbated by additional falls in the oil price, together with the structural adjustment programme forced on Nigeria by the International Monetary Fund and the World Bank (Falola and Heaton 2008), the negative consequences of which continue to resonate. Moving the national capital from Lagos to Abuja in 1991 eliminated much of Kaduna's political importance, while the deterioration of the infrastructure resulting from the economic problems gradually forced the closure of most large textile factories (Andræ and Beckman 1998).

Decades earlier, the need for skilled workers for these factories had enticed southern Nigerians to the city, greatly increasing the number of Igbo and Yoruba inhabitants. While the men found jobs in the larger plants, many of their womenfolk were employed in ancillary workshops. With the closing of the large enterprises these were unable to continue either, forcing entire families into the informal sector (Andræ and Beckman 1998; Meagher 2013).

Little has improved since then, including the infrastructure. As long as they can access oil revenues, elites continue to lack incentives to establish major enterprises. The accepted route to these is via political office, which provides significant enough gains to warrant the use of violence to help win elections, as well as facilitating the corruption that has become endemic in this nation (Harris 2013).

Perhaps as a result, several serious episodes of violence have occurred in Kaduna State, allegedly as a consequence of elite power struggles. ${ }^{7}$ In the city the worst outbreaks were over the introduction of shari'a law in February and May 2000, over Nigeria's hosting of the Miss World beauty pageant in November 2002, and in protest at the re-election of Goodluck Jonathan in April 2011, with total deaths in the thousands, many more wounded, and large numbers displaced. Besides the loss of life and limb, there was considerable destruction of property, which people received no compensation for, so that each successive outburst impoverished further segments of the population. This has been exacerbated by the fact that many people have decided mixed-religious neighbourhoods are unsafe. This has brought thousands of Christians to relocate south of the river running through the city, Muslims to shift north. One effect has been that many employees must now travel long distances to work, significantly increasing their financial, time, and stress burdens (Harris 2013).

\section{Christianity and Islam in northern Nigeria}

Islam arrived in what is now northern Nigeria well over a millennium ago, for centuries being mostly taken up by elites. The early nineteenth century witnessed the jihad of Usman Dan Fodio, essentially a crusade to rid Islam of local accretions, the influence of which is still being felt (Andersson 2002), while missionaries only started spreading Christianity among the population at large in the late nineteenth century. The twentieth century saw the vast majority of the population convert, so that 
today at least 95 percent of the Nigerian population claims adherence to one or other religion, often alongside the continued practice of elements of local rituals and cults noted above (Pew 2010).

In the 1840s, Christian missionaries settled in the coastal regions, gradually moving inland. During their conversion efforts, they paid significant attention to inculcating European gender norms into their congregants, apparently conflating their own gender ideals with appropriate Christian behaviour (Oyěwùmí 1997: 128ff). Officially, missionaries were supposed to stay away from northern Nigeria, by agreement between the colonial administration and the emirs or rulers, and the majority of the local Hausa population converted to one of the two Sufi orders - the Qâdiriyya and the Tijâniyya - that dominated Nigerian Islam at the time (Falola and Heaton 2008).

By the late twentieth century, a preponderance of the inhabitants of southern Nigeria, as also of the southern regions of the middle-belt states, including Kaduna, had converted to Christianity, mainly to a mission church or ECWA (the Evangelical Church of West Africa ${ }^{8}$ ) (Pew 2010). It was in this central region that the two religions met in relatively equal proportions. Perhaps not surprisingly these have been the arenas of the greatest sectarian unrest, exacerbated by the indigeneity laws (Kraxberger 2005).

The government response to the oil boom-and-bust of the 1970s and 1980s acted as a catalyst for the dissatisfaction of the populace, particularly the more educated middle classes, prevented from moving up the social ladder and finding themselves instead sliding into poverty, due to the economic situation and the power of the elites, while taunted by the latter's increase in conspicuous consumption. These feelings were exacerbated by the hierarchical character of Nigerian society, which kept young people and the lower classes in positions of servility despite some undermining of the social structures by nouveaux riches who had managed to grab some of the oil wealth for themselves.

Several further factors influenced the situation. The first was the conviction that occult powers were ultimately responsible for this surge in wealth that appeared to lack a productive source. The second was the belief that the Sufi orders and established churches participated in state-related corruption. This was accompanied by resentment that these institutions were doing little to help their congregants deal with their difficult socio-economic situations and that they provided no support for confronting the causes. The third was the increasing feeling that a purely secular state would be unable to meet the people's expectations, especially in terms of getting rid of corruption (Falola 1998; Kane 2003; Marshall 2009).

The populace's growing alienation from the state and mainstream religious establishments helped both Muslims and Christians view this as a crisis that could be met only by 'recourse to supernatural means ... as a technique or practice of power' (Marshall 2009: 104). Among those most 
strongly affected were young, educated, lower-class men whom the gerontocratically-based hierarchies of Nigerian society had tended to repress. Not only did they not belong to the elite but they were expected to follow the lifestyle ordained for them by parents and society. Hausa Muslims, for example, were required to kowtow not only to the elders but also to the Sufi Shaykhs whom they must beg to intercede for them in religious matters (Kane 2003). It was from student associations, Christian-based in the south, Muslim in the north, that the notion of establishing new religious institutions emerged. This was significantly affected by the 1977-78 debates in the Constitutional Assembly over introducing shari'a law in the north, as well as by transnational influences including new forms of Pentecostalism from the United States, the expansion of Saudi Arabian support to northern Nigerian Islam as a way to spend excess petro-dollars, and the Iranian Revolution. The outcome was new charismatic, mainly neo-Pentecostal, churches and a wave of reform Islamic and Islamist movements (Kane 2003; Marshall 2009). ${ }^{9}$

The latter included the Umma, or 'Shiites', under their charismatic leader, Ibrahim El-Zakzaky, inspired and supported by the Islamic Republic of Iran, Maitatsine's millenarian movement, and more recently the Islamist, Jama'atu Ahlis Sunna Lidda'Awati Wal-Jihad, popularly known as Boko Haram, whose founder, Mohammed Yusuf, was killed by the state in 2009 (Ben Amara 2011).

In this paper I focus almost entirely on the largest and most influential of the reformist movements, the Society for the Removal of Innovation and Reinstatement of Tradition, known as Izala, ${ }^{10}$ which has particularly strong connections in Kaduna. Izala was founded in 1978 by Ismail Idriss but its salafi-based ideological and theological underpinnings mainly derived from the teachings of Idriss' mentor, Shaykh Abubakar Gumi, a controversial but powerful figure in northern Nigeria in the second half of the twentieth century, who made his headquarters in Kaduna city (Ben Amara 2011; Marshall 2009).

The primary aim of Izala was the removal of accretions alien to the Sunna. ${ }^{11}$ To accomplish this it launched fervent and highly public attacks on the Sufi orders and their 'sacrilegious' practices. These included the treatment of objects as sacred, the custom of worshipping at the shrines of saints, and the elevation of living Shaykhs to high positions as the sole qualified mediators between the population and Allah. Gumi explicitly categorised the 'spiritual economy' of Sufism as based on claims of the capacity to deal with magic powers, which he saw as blasphemous and exploitative of the credulous. In his eyes, Izala stood for the notion that individuals had the right and indeed the obligation to read the holy writings for themselves, make their own reasoned interpretations, and take responsibility for their own salvation (Kane 2003: 129-130).

In addition to theological differences, Izala opposed the hierarchical relationships within Sufism through which Shaykhs were viewed as practically divine. It intended to forge a new kind of 
Muslim - more individualistic and independent, and so willing to limit involvement in the complex social web that accompanied Sufism, including the widely extended family. Izala would replace steep class hierarchies with more egalitarian relationships (Ben Amara 2011; Marshall 2009).

This approach is similar to that of the new charismatic churches also established in the late 1970s. They too saw themselves as returning to a purer version of religion in opposition to the missionary orders and as espousing greater democracy, like Izala rejecting social hierarchies including those of the mainline churches. While most new churches had their origins in southern Nigeria, several of the more influential also have branches in the north, especially Kaduna, which has been a centre of charismatic revivalism, owing to its large Christian population and its former status as the administrative centre of northern Nigeria. Among the most prominent Pentecostal churches there are the Living Faith Church (popularly called Winners Chapel), and the Deeper Life Bible Church/Christian Ministry (Ojo 2007).

Both Izala and the new charismatic churches looked to produce new ideals of personhood and individual responsibility in ways that repudiated and battled with the established orders they often considered corrupt and even hand-in-hand with the devil and his workings. They wished to cleanse religion from negative influences viewed as emanating from both established institutions and local cults and rituals. In many ways, echoing the sentiments of the earlier missionaries, this has brought them to aim for a complete rupture with these elements of the past (Marshall 2009).

This engendered considerable hostility, exacerbated by a significant loss of mainline congregants to the newer institutions and the conversion of Muslims. In order to combat fragmentation within each religion, umbrella organisations were founded - the Christian Association of Nigeria (CAN) in 1976 and Jama'at Nasr al-Islam ${ }^{12}$ (JNI) in 1962 (Kane 2003; Marshall 2009).

More recently a certain level of unification has resulted from the politicisation of religion, producing Muslim-Christian competition for the Nigerian state. This was first explicitly articulated during the shari'a debates of the late 1970s and continued in the following decade with disputes over Nigerian membership of the Organisation of Islamic Cooperation (Ben Amar 2011; Loimeier 1997), alerting Christians to the importance of uniting to prevent the Nigerian state becoming Islamised.

This moved the charismatic churches in particular to rethink their previous stance of concentrating on individual salvation through prayer and the renunciation of the devil, realising the state was too important to leave to the Muslims. The new religious movements started to question the very notion of a secular state. Each side wished not merely to control the state but also to banish demons and corruption through placing their own religious brethren in charge in order to bring the state into line with their ideology. Izala leaders resented the long-standing Sufi domination of the state and expressed a wish to impose shari'a law on the north, while the leaders of the larger 
Pentecostal churches began to campaign for political leaders from their own denominations who would purify state institutions (Kane 2003; Kukah 1993; Marshall 2009).

As a result, while intra-religious friction continues to this day, spurred on by competition over souls, it has taken second place to political competition. This has pitted Christians and Muslims against one another, heightening the salience of the religious divide and encouraging both intra-religious unity and inter-religious conflict.

\section{Gender in Nigeria}

As stated above, it is my contention that pre-colonial Nigerian cultural groupings did not organise according to gender in the sense of a hierarchical system whereby males are categorised as inherently superior. They did, however, have socially-constructed differentiation in terms of expected roles and behaviour patterns of males and females, with considerable cultural variation in social organisation among the disparate peoples. The lack of a biomedically-based understanding of malefemale relationships facilitated a fluid attachment between sexed bodies and social roles. Thus, in a number of cultural groups it was accepted that, when required, women could be conceptualised as male, men as female. Hence, Ifi Amadiume (1987) explains that among the Igbo, in the absence of a son, a daughter could be formally allotted male status and be expected to carry out male-related activities, both public and private. Women could be conceptualised as husbands and marry wives, who would fulfil the same roles as if married to biological males, bearing children for the lineage through a man selected for the purpose. The Igbo term for head of household was not gendered and the position could be taken by either sex depending on the situation. In various parts of Africa in the absence of appropriate women, male youths could formally become wives for adult men (Carrier and Murray 1998).

Regarding northern Nigeria we have less information about historical power relations among Muslim Hausa. While their pre-Muslim forebears did not appear to regard women as inferior (Andersson 2002), we know little about what conversion to Islam changed or how male-female relations were affected by the early nineteenth century jihad of the Fulani leader Usman Dan Fodio. Dan Fodio regarded his daughters very highly; one of them became an important scholar and political leader in her own right, training a team of women to reach out and educate others (Mack and Boyd 2000), despite female seclusion being encouraged for elite Fulani Muslims.

It was under colonialism that the majority of Hausa converted to Islam and it was then too, in great part as a form of political resistance, that lower-class Hausa Muslim women started to be routinely secluded as they are today, although this is not as strictly implemented as in the Middle East and South Asia (Imam 1994). Seclusion permitted women to avoid back-breaking agricultural labour 
and afforded them the opportunity to establish their own small businesses. Some apparently welcomed this to the extent of converting to Islam to gain these advantages. Muslim law permitted them to keep their profits for themselves except in cases of extreme family need, so it was not unusual for Muslim women in northern Nigeria to be wealthier than their husbands (Coles 1991; Jackson 1985).

Gender, as the hierarchical concept it now represents (Tamale 2013) was brought to Nigeria in the late nineteenth century by western missionaries and colonial officials. It was a crucial element in the 'civilising mission', the concept used to legitimise European domination of the global south (Prevost 2010). Despite clashes over colonial politics (Hansen 1984), church support was deemed indispensable for carrying out this mission and nowhere more so than in Sub-Saharan Africa. Here, a fundamental aim of both church and colonial state was the inculcation of Europeanised norms of gender performance in peoples to whose thinking this was ontologically alien (Amadiume 1987; Labode 1993; Nzegwu 2006; Oyěwùmí 1997). Besides the notion of inherent male superiority, one of the most insidious tenets that accompanied this was the notion of hierarchies of masculinities, headed by the form inculcated into the British male elite in their 'public' schools. This legitimised the notion that white middle-class and elite men should occupy the highest positions in a global hierarchy (Sinha 1995). ${ }^{13}$

In colonial Nigeria missionaries both acted as role models and inculcated appropriate gendered behaviour in line with that of their own backgrounds. One way they did this was by differential schooling for boys and girls, in which the former were instructed in academic subjects, the latter mainly in housekeeping skills and appropriate female comportment (Labode 1993; Oyěwùmí 1997).

This distinction was compounded by the colonial authorities, who made it clear that, despite Nigerian women's major role in production, waged labour was a man's affair. Educated men were offered skilled employment in the civil service and on the railways, while girls' schooling prepared them for domesticity (Lindsay 2007). Christian women were taught their place was to act as helpmeets to their husbands; they could not become church leaders in Nigeria, any more than elsewhere at that time (Prevost 2010). Since the British openly placed a much higher value on men and male activities than on women and female work (Nzegwu 2006), this influenced Nigerians' own perceptions, so their men started to believe in their own superiority. This was enhanced in the postcolonial setting by white male development practitioners, who influenced cultural groups previously little affected by these ideas, including by establishing men as superior in law, for instance, by granting them as household heads the right to register land ownership in their names (Rogers 1980). It is thus 
hardly surprising that today the notion of male superiority has become firmly entrenched in Nigerian society as an unalienable and supposedly undisputedly traditional element of gender relations.

\section{The four foundational elements of contemporary masculinity in Nigeria}

The effect of missionary efforts was not to cause Nigerians to abandon their socially based power structures but rather to combine them with aspects of westernised notions of gender (Amadiume 1987; Nzegwu 2006; Oyěwùmí 1997). Today, Nigerian society is organised not only along gender-power lines but also along lineage- and age-based ones whereby older or senior men hold higher power positions than youths and older women retain in practice far more power than the Europeanised terminology would suggest. I have called this last tacit power - that is, power not expressed in public discourse (Harris 2006, 2012a; see also Jackson 1985; Nzegwu 2006).

Meanwhile, the ability of men to project appropriate masculine traits has become essential to their status and that of their families. A few of these characteristics are particularly crucial, comprising what my research has shown to be foundational elements, common to the majority of patrilineal social groups I have worked with globally over the past two decades, and quite clearly visible in the characteristics of masculinity identified by our project participants in Kaduna (Harris 2011). I am suggesting neither that these directly reflect actual practices, although they affect them strongly through pressures to conform, nor that they are either inherent in human biology or culturally universal. Rather they derive from exposure to similar influences through (neo)colonialism, including international development and neoliberal capitalist globalisation, supported by western media. These elements are: control over material resources/breadwinning; control over human resources, particularly wives/children; virility; and the performance of bravery/protection, very often through forms of violence.

\section{Breadwinning - control over resources}

Largely as a result of the colonial introduction of capitalist ideology, masculinity in Nigeria became linked to both control over resources and the obligation to act as the sole provider of economic support within the family. Consequently, men were conceptualised as wage earners and the ability to earn a living became attached to notions of masculinity even while the majority of men never attained this goal, working either as smallholder farmers, along with their wives, or informal labourers.

Although ideologically, superiority is inherent in (adult) men, this is to a large extent understood as dependent on their capacity to wield sufficient material resources to satisfy their families' needs. This suggests control over wives and even older offspring is predicated on the ability to provide adequately for them. Thus, it is less the dispositional positioning of men as superior and 
more their ability appropriately to perform provider masculinity that obliges women and children to obey their husbands/fathers (Harris 2012a). Therefore, a man unable at least to project the image of complying with this ideal may well find himself imbued with less authority than he feels entitled to by his positionality, either within the family or the community at large since 'a man that cannot provide for his family is term[ed] as useless in the society'. ${ }^{14}$ This makes men particularly vulnerable to the vagaries of neoliberal market regimes in contemporary society, as we shall see.

\section{Gender/age positionality and control}

In gerontocratic societies such as Nigeria, age- and gender-based hierarchies intersect, with mature men epitomising the ideal masculine position - in control of wives as well as offspring - while mature women hold a secondary position - higher than young people of both sexes but lower than their husbands. Young women have the lowest status of all while young men occupy an intermediate position. As males they should be strong, controlling, and visibly working towards attaining the economic capacity to marry and support a family. However, as youths they are expected to show subservience to both parents but particularly to fathers (Harris 2012a).

The legal age of majority might be eighteen but culturally young people are not considered adults until they are married with children. This usually requires family support as wedding costs are significant, making youths dependent on their fathers to help them marry, and thus emphasising the generational aspect of gendered power relations. As long as a father appears likely to be capable of financially supporting his sons' marriages as well as their educational aspirations, the gender/age hierarchy may be respected. Fault lines are revealed, however, when older men are clearly unable even to provide adequately for daily living expenses, creating a fear these lines may well grow to the point that wives stop accepting their husbands' right of control, something seen as threatening the very fabric of society. Today this is considered by men in northern Nigeria as particularly problematic because of the important role the capacity to demonstrate such control plays in contemporary claims to upholding the Islamically-based morality that has accompanied the introduction of shari'a law (Gaudio 2009). Pentecostal Christians also consider the man to be the rightful head of the family (Marshall 2009).

\section{Virility}

A further crucial characteristic of masculinity resides in its relationship to sexuality. As a result of European influences, religious and temporal, in Africa masculinity is now conceptualised as inseparable from penetration, femininity from the penetrated. This both constructs men as active, as opposed to passive women, and simultaneously suggests anyone who allows themselves to be penetrated becomes feminised, while penetrators, whether with a flesh-and-blood penis or a penis 
signifier, are masculinised. Thus, in Africa, as in the global south more generally, deviance from appropriate gender-related behaviour is considered particularly problematic in claims to nonheteronormative identities although scriptural proscriptions also play an important role (Ratele 2011).

From the ontological perspective of pre-colonial Nigeria these notions would have made no sense. Sexual practices in Sub-Saharan Africa as a whole were fluid and not bound up with identity claims (Tamale 2013), which are after all relatively recent even in Europe (Foucault 1990). It is likely they evolved there because the patriarchal gender ideals that had developed by the mid-nineteenth century partially through increasing emphasis on identity differentiation forced those whose practices did not accord with the constructions of masculinity and femininity given in the previous paragraph to start making claims to specific identities of their own. Thus, the very notion of heteronormativity was brought to Africa by Europeans, along with Christianity and colonialism. In Nigeria, as in other British colonies, (male) homosexual practices were criminalised by legislation that followed the British law of 1885 (Long 2003).

Since virility cannot be demonstrated directly, proxies are used. In Nigeria the two main ones are first men's visible capacity to access multiple (female) sex partners, preferably even for Christian men in the form of multiple wives, and secondly numbers of children, particularly sons. Historical evidence suggests wealth production in Sub-Saharan Africa depended mainly on the size of the labour force, for most consisting entirely of family members, thus, encouraging polygyny (Shaw 2002: 157). Despite subsequent material changes, for many this remains strongly associated with men's status. Underlying this all are the assumptions that a real man penetrates (and impregnates) women but also that he is able to provide material support for his wives and children.

\section{Bravery/protection}

In some parts of pre-colonial Nigeria, women could be warriors, demonstrating bravery and acting as protectors of their group; however, overall this remained an attribute of younger men (Achebe 2005). To be a brave warrior was in many places an important youth aspiration and this is still the case, since this group is largely unable to attain any of the three elements previously discussed, which are essentially traits of adult men. Today, the performance of violence, whether public, as in participation in rebel armies, gangs or riots, or private as within the household, remains one of the few ways in which men unable to live up to the previous three elements can claim masculinity. ${ }^{15}$ 


\section{Failures of the social order}

\section{Religion in Kaduna}

Kaduna has been worse affected by the economic woes described above than many other parts of Nigeria, exacerbated by the multiple episodes of violence discussed above. Not only has there been no compensation for loss of property but the population movements mentioned have been costly in multiple ways, especially the fallout from the suspicion and uncertainty that now surround inter-religious relations (Meagher 2013).

This has been further aggravated by the attempts of the city government, apparently at the behest of the Emir of Zaria, to remove indigeneity rights from local Christians, something that particularly affects the Gbagyi. As young people reach the age of majority many are no longer able to obtain the appropriate certificates, despite their parents and grandparents possessing them (Harris 2013). This has greatly increased inter-religious tensions, as discussions I held with youths, their parents and Christian clergy testified.

The overall result is that uncertainties and instability remain high, feeding into the need for both emotional and material support as well as for answers to the question of the underlying causes of these problems. In the past, local cults or rituals would have been the obvious place to look and for some this is still the case. However, most of those with whom I spoke preferred to turn to the new religious institutions. As Falola suggests:

the failure of the nation-state and of secular ideologies have enhanced the relevance of religion. Religion continues to provide many alternatives to social ills: hope that the future will be bright for millions of people traumatized by the failure of government; the emotional strength to handle stress; shared identity for the hopeless and the marginalized in cities and towns; respect and status within missionary hierarchies; and social support for women troubled by poverty, childlessness, and spousal abuse. To those who yearn for power or democracy, religious organizations provide leadership opportunities in the establishment and administration of new branches. Where religion is lucrative, more than a few have made a business of it, using their charisma and organizational ability to raise money in novel ways (1998: 37).

The relatively recent founding of Kaduna city meant the Sufi power structures were less deeply embedded in the social system there than elsewhere in the north. Moreover, Shaykh Gumi's establishing of his headquarters in the city brought particular prominence to Izala, supported by the large and prominent mixed-sex secondary school run by the institution. The consequence has been that large numbers of Muslims have joined Izala.

Meanwhile, a plethora of charismatic churches has sprung up in Kaduna. On each of my visits, I saw several new ones. While Deeper Life and other churches of the late 1970s and early 1980s focused on 'holiness', judging by their billboards many of the more recent ones belong to the 
prosperity movement - that is, they promise true believers salvation in this world and are adamant it can be recognised not only through spiritual power, although this remains important, but also through material prosperity. Thus, the simple living advocated by Deeper Life has given way to the display of visible symbols of wealth. Prosperity ministers place increasing emphasis on healing the sick but also on 'global spiritual warfare and ... personal miracles of deliverance', hopefully leading to wealth (Marshall 2009: 79). Winners Chapel is the most successful representative of this group in Kaduna (Ojo 2007).

\section{Men and masculinities in Kaduna}

One consequence of Nigeria's economic problems has been that significant obstacles have been placed in the way of the vast majority of men ever achieving the breadwinner norm, particularly the many rural men migrating into the cities, lacking skills or connections to gain formal employment. In other words, the introduction under the British of a capitalist-based economy produced the correlation between breadwinning and masculinity noted above. The lack of corresponding opportunities for waged labour has seemed almost like taunting to Nigerian men, so few have ever been able to attain this, in large part because of their country's position in the global political economy.

Despite their now having the largest GDP in Sub-Saharan Africa, ${ }^{16}$ Nigerians, especially in the north, have remained among the poorest inhabitants of the continent (Teal 2014). The economic situation in Kaduna has continued to worsen, significantly limiting access to employment, especially for youths (Bununu et al 2015; Harris 2013). In fact, employment opportunities have been steadily dwindling, not only for the less educated and unskilled but also for educated and skilled men lacking useful connections. This means the majority of the city's mature male inhabitants have been unable fully to live up to the provider role and this is likely to be even harder for their sons.

The Muslim women in the projects recounted how in the evenings they would wait for their husbands to bring home money, provisions, clothes or shoes for the children, as well as household supplies. More often than not their menfolk were unable to procure even sufficient food for the day, let alone any less crucial items. Since it is believed Islam has tasked men alone with supporting their families ${ }^{17}$ and since Hausa Muslim women are supposed to remain secluded, even the poorest are debarred from going out to work. The economic woes of the 1980s had seemed to be going to change this (Coles 1991). However, by the mid2000s the less educated women with whom we worked were still secluded. Even the widows and divorcees were faced with strong pressures, which few could withstand, from neighbours and family members intent on stopping them from taking a job. One woman described how the nasty comments flung at her by her neighbours made her daily journey to 
work a torture but she persisted since she had no other means to ensure her own and her children's survival. This does not, of course, mean no educated Hausa Muslim women in Kaduna hold formal jobs, nor that other secluded women do not manage to earn decent money. However, according both to our facilitators and our participants, such women remain in the minority and almost none ever participated in our projects.

Seclusion particularly legitimises women's demands that their husbands live up to their provider roles. The project women had taken on board the notion of male superiority, assuming this meant their husbands would be fully capable of carrying out their duties, with no more obstacles than they themselves met with when they demonstrated their ability to fulfil the obligations of a good Hausa wife and mother. They thus felt justified in accusing the men of a failure of manhood in not carrying out their part and, according to their own testimony, would do this loudly and aggressively, not only in front of the children but at times even more publicly, something apparently quite common in Hausaland (Salamone 2007). The humiliated men would in turn become aggressive and might even beat their wives. It was bad enough they were failing to perform competently the breadwinning norm but to have this publicly exposed meant double humiliation, as it further revealed their inability to control their wives, and thus their failure to meet either of the first two elements of masculinity.

Serious economic hardships were common among these families. The women tried to find ways to earn money within the boundaries of their homes. However, since most were not only illiterate, but also lacked the skills to produce marketable goods, the main way secluded women can generate income, this was not easy. To improve their situation, the project taught them to make lotions, soaps and other small items so they could meet some of their personal needs even if they could never earn enough to support their families.

The situation of the Christian women in our projects was little better despite the majority having some level of schooling. However, a number of their husbands had been influenced by Hausa neighbours into considering female seclusion an appropriate mark of masculinity. They thus refused their wives permission to take a job. Other women either lacked appropriate skills or were unable to find work. The most they could do was some form of petty trading, so they too started producing and selling the items they had learned to make in our project.

Mature men from both religious groups complained their wives wanted them to be 'heroes' by bringing home the kind of money only someone with a decent salary could achieve. ${ }^{18}$ They did not appear to realise this myth had been created by their own insistence on their masculine superiority, as evidence from the women in our projects demonstrated. This was not, of course, a mere personal whim but emanated from the men's need to live up to social expectations in order not to appear emasculated before family and community, while trapped in circumstances that made it impossible to 
achieve this. The situation appeared particularly difficult for the husbands of our Muslim participants with less education and fewer skills than their Christian peers, and with even greater pressure to live up to religiously-inspired notions of men as sole providers. They were also more likely to be polygynous, to have many children, seclude their wives, and in some cases not to send their daughters or even sons to school, thus increasing the likelihood of poverty in the next generation. ${ }^{19}$

The young men of both religions with whom the project worked were trying hard to earn money to pay their school fees or save for tertiary education. They put great store on this as a path to improving their life chances. Most of them desperately wished to attend university although they realised they were unlikely to succeed, since not only is there fierce competition, with hundreds of applicants for each place, but the costs are prohibitive.

One consequence of their inability to depend on husbands and fathers to meet family needs has been that wives and older sons have started to challenge the men's power position. Particular frictions were exhibited in a group of Christian families who farmed small plots of arable land on the outskirts of the city. The fathers expected their sons to provide unpaid labour, which greatly annoyed the youths. Finding it awkward directly to confront their fathers, they preferred to vote with their feet - after school slipping away to help in the local market or work on the land of another family willing to pay them. The effects on the older men have been devastating. Unable to meet all demands for economic support, they nevertheless continue to insist on their right to the upper power position that is, to retain the high levels of dispositional power they feel entitled to as mature men (cf. Harris 2012a).

Bourdieu suggests those in dominated groups (in this case women and youths) have been conditioned to accept such dispositional power as superior and that it would take 'a radical transformation of the social conditions of production' to change this (Bourdieu 2001: 39, 41-42). Things have not quite reached this level yet in Kaduna but change is in the air. Young men in particular show themselves unwilling to continue unconditionally to obey a father who can pay neither for their schooling nor for their marriage. This is a society in which a man is expected to meet the costs of his sons' weddings, including fees for the officiating clerics and bridewealth. The groom must also provide the couple's home and show himself capable of supporting his wife and future children. In the current economic climate this is a major challenge. Muslim girls are likely to have arranged marriages as they are not supposed to know any potential suitors. However, their Christian peers did expect to choose for themselves and apparently tended to put economic capacity at the top of the list of the qualities they sought in a life partner.

Young men of both religions complained bitterly they were unlikely to be able to marry until they were far older than their fathers had been. The Christians were additionally highly critical of the 
materialism of the girls they were interested in who would not even look at a man unless he had a good job or came from an economically well-established family, preferring a polygynous relationship with an older man to life in poverty as first wife to a younger one. These issues are particularly problematic in this society in which marriage and the production of children comprise the essential rite of passage from youth into adulthood (Salamone 2007), suggesting some may never attain the latter status.

Additional pressures arise from the fact that family members in the home village take it for grant that their urban relatives have money on which they have a right to draw, making it even more difficult for men to meet their daily responsibilities let alone put money aside for future needs.

\section{Masculinity and religion - symbiotic resources}

While the majority of the Nigerian population is poverty-stricken, the fact that both older elites and a small number of newcomers able to position themselves advantageously in the political hierarchy have continued to benefit very considerably from the oil money (Falola and Heaton 2008) is seen by the population at large as proof they resort to occult powers. The absence of evidence of how the wealth was produced has made the riches appear somewhat like manna from heaven or the outcome of a pact with the devil (Marshall 2009).

The conjunction of the authoritarianism of the military governments who ruled most of the time from independence to 1999 , the fact that too little of the oil money has been used for the benefit of the population as a whole, and the considerable violence that has plagued the country over the last few decades, has meant that for the majority of urban inhabitants, especially in the north, poverty has been compounded by threatening social chaos. This has been exacerbated by a lack of investment in agriculture that until the new millennium fuelled rural-urban migration (Teal 2014), thus greatly swelling the population of Kaduna and other cities.

In the absence of alternative forms of support, many have found their biggest solace in religion. As previously stated, Nigerians have long been accustomed to looking to the supernatural for both cause and cure for the ills that beset them and nowadays this usually means looking to church or mosque, and for many to reform Islam or the newer charismatic versions of Christianity. Many see these as more relevant for their current needs than what is provided either by the older religious institutions or the traditional rituals and cults. First, they offer a clear explanation for the pejorative comportment of the government and the elites, as well as for the negative consequences, an explanation that fits well with the vision of the world expressed above - a vision of good and evil, with corrupt officials seen as sinners under the sway of Satan/Shaitan. A second but very important scapegoat is presented in the form of demonization by each side of the other religion, thus 
legitimising violence against its members (Marshall 2009). Falola describes how some Muslims saw Jesus as the devil incarnate, while Christians insisted Muslims performed religious ablutions in Christian blood. These opinions are said to represent those of considerable numbers of members of each religion and to be an indication of the prevailing regime of symbolic violence in Nigeria, a regime that dates back to the time when early Christian missionaries started the practice of vilifying Islam as an element in spreading the gospel (Falola 1998:37, 247-248).

Such unambiguous accounts of the ultimate causes of the poverty and unrest currently plaguing Nigeria have been accompanied for both religions by instructions on how individuals can get the better of the evils threatening them through defeating their own devils. This includes closer and more personal relationships with God/Allah, as well as, for Muslims, the abandoning of local accretions that placed Sufi Shaykhs in positions of authority. These new institutions then provide congregants with paths to salvation as well as to understanding the world around them. In addition, the neediest members usually gain some level of material support, an essential safety net in the form of cash and other social benefits, most paid for by tithing/zakat ${ }^{20}$ from wealthy congregants (Marshall 2009).

The older institutions have become concerned as they see their congregations shrinking, as I heard from several Anglican priests, including the Archbishop of Kaduna. The Sufi Orders have expressed alarm at the influence of more radical groups on youths and have started to offer material benefits to their own congregants in the hope of keeping them within the fold, especially the provision of free religious education (Hill 2010).

Izala has become the largest Islamic reform movement in the region. This is in part because of the benefits it provides in the way of legitimising personal rights to make individual decisions about religious matters and to come to one's own conclusions about the meaning of the scriptures but also because of what it offers the socially marginalised. It has cut through the traditional hierarchies of Hausa-Fulani society to treat all as worthy of respect, for instance, by insisting its members not continue the practice of kneeling to elders and the powerful. Izala has further helped its members by significantly reducing the high prices charged by Sufi Shaykhs for officiating during rites of passage such as weddings, funerals, circumcision and baby naming ceremonies. Other economic advantages derive from reducing or eliminating bridewealth for marriages within the sect and the strong suggestion that members limit themselves to supporting their immediate family members, rather than their wider extended family (Kane 2003: 136).

The neo-Pentecostal churches have approached these issues in much the same way, some even going as far as to forbid members to have anything to do with parents or siblings who do not belong to the same church, and offering their fellow congregants as a substitute family (Maxwell 
1998). The prosperity churches additionally promise salvation in the 'here and now', a way of dealing with the vicissitudes of neoliberalism in which material success becomes synonymous with righteousness (Larkin and Meyer 2006; Marshall 2009: 13, 24, 174-5). The belief that poverty and misfortune are ultimately the fault of malevolent ancestral spirits still plays a role but these churches provide a new path to dealing with this, intended to make rituals and cults irrelevant while boosting individual material wealth (Marshall 2009; Maxwell 1998).

All this helps improve the economic situations of members of both religious movements. Doing away with the obligation to provide for everyone with family-related claims, however distant the connection, has made it easier for many men not only to meet their wives' and children's daily requirements but also to save for their sons' weddings. Lowering officiating costs and getting rid of bridewealth has considerably reduced expenses, thus facilitating the marriages of impoverished young men such as those our project was working with in Kaduna.

However, the newer religions impose their own behavioural standards, curtailing the liberties of their congregants in various ways. First, they do not tolerate any resort to traditional rituals. Members must follow sect-specific approaches for combating evil. Secondly, they dictate appropriate gendered comportment - extra-marital sexual relations are forbidden, as is alcohol consumption. There are strict rules about dress, particularly for women. For the Christians, this has meant conservative clothing. For instance, Deeper Life in its early days

forbade its followers to watch television or drink soft drinks such as Coca-Cola. Women were told not to straighten or perm their hair, and not to wear jewelry or trousers.... [C]onverts were continuously exhorted not to lie, cheat, steal, quarrel, gossip, give or take bribes, drink, smoke, fornicate, beat their spouses, lose their tempers, or deny assistance to other members in need. Strict dress codes were imposed, and limited contact was allowed between the sexes. Marital fidelity was a central tenet, and divorce was not sanctioned (Marshall 2009: 71).

While this might seem limiting, the constraints on male behaviour improved women's lives, significantly reducing levels of domestic violence and enhancing marital relations. From the start of the twenty-first century the church somewhat relaxed its severity. For instance, members are now permitted to watch suitably edifying television programmes. Although, unlike holiness churches such as Deeper Life, the Winners Chapel and other prosperity churches encourage the wearing of fashionable clothing and visible signs of wealth, they still expect adherence to strict standards of propriety in dress and general comportment (Marshall 2009).

Under the guidance of Shaykh Gumi, Izala in northern Nigeria has from the beginning supported certain emancipatory measures for women, including some measure of freedom from seclusion, as long as appropriate dress is worn. Thus, the influence first of Izala and later of shari'a law has meant that the vast majority of Muslim women in northern Nigeria now wear an all-covering cloak 
similar to the Iranian chador (Nasir 2007). Moreover, in the last few years in Kaduna, Saudi influence via returning male migrants has started a fashion of wearing niqab, that is, the face veil, in addition to hijab.

Gumi put great stress on women's education. Illiterate housewives were invited to attend Qur'anic schools, in which they did not simply learn to recite the scriptures by rote as in the popular Sufi schools but were taught to understand Arabic so they could read and interpret the holy writings for themselves. In this way they could join their menfolk in becoming 'true' Muslims, taking charge of their own religious beliefs and understanding, unlike members of the Sufi orders who rather than reading the Qur'an submitted to the authority of the Shaykhs (Ben Amara 2011; Kane 2003; Larkin and Meyer 2006). To this end Izala has undertaken mass schooling of women (Kane 2003; Renne 2012). Nevertheless, Gumi did not advocate anything like equality. He insisted women and men should be segregated as far as possible and the former should limit their participation in public life. While voting for women was strongly encouraged, since this was important to keep Muslims in power and Gumi also encouraged the founding of a Muslim women's movement in northern Nigeria (Loimeier 1997: 169), holding public office was frowned upon. Women had to know their place and above all they should not aspire to behave like western women and demand equal rights (Kane 2003: 142). My discussions with Izala Imams suggested such attitudes persisted. Some, for instance, require their wives to cover face, hands, and feet in public, leaving only their eyes visible.

The charismatic churches are little more relaxed in relation to women. They admit them to some leadership positions but generally keep them in second place. In effect, both reform mosques and Pentecostal churches encourage women to play active roles while simultaneously promoting masculine superiority. Thus, women's higher profile and greater opportunities in their places of worship come at the cost of expectations of submission to male authority (Marshall 2009).

Both religions seem to hold special appeal for young urban men who feel themselves marginalised, particularly but not only the more educated. Many project youths had been raised in one of the newer sects/denominations but some had enlisted in their own right. Izala and many Pentecostal churches uphold generational power only for young people whose parents are also members since only their own members count as true believers and they see no reason why youths should obey sinners. Nevertheless, men old and young can console themselves with the fact that women are kept firmly in their place; they may have to be treated with respect but they are also required to subordinate themselves to their menfolk. Men's power position is bolstered by taking a wife from the same congregation who is virtually guaranteed to behave appropriately, while young women are discouraged from putting wealth in a marriage partner above godliness, accordingly increasing young men's chances of marriage. Weakening the authority of the older generations also 
supports youths to adopt more individualistic lifestyles (Kane 2003; Marshall 2009). Thus, the newer religious establishments go some way to help men conform to the first two foundational traits of masculinity, albeit with somewhat flattened-out gerontocratic elements.

The newer religious movements have attacked some of the premises on which the third element of masculinity, virility, has historically been based, most especially multiple sex partners, which the neo-Pentecostals in particular frown upon. Perhaps a show of strong antipathy to nonheteronormative practices is a way to provide a substitute by demonstrating an appropriate approach to sexuality. Whether or not for this reason, the populace appears strongly to support the position both of their religious establishments and the Nigerian government that homosexuality is evil and destructive of the social order. After all, it threatens the third element of masculinity (Ratele 2011) and is a major sin for both Christianity and Islam. Taking advantage of the fears that many feel as a result of these, governments have found it a very useful scapegoat for deflecting attention from their own failings or ramping up popularity at election time (Tamale 2013).

This is exacerbated by the association on the part of the religious institutions of nonnormative sexualities with witchcraft and demons. As a result of this and the introduction of shari'a law, groups in northern Nigeria who are indeterminately sexed and/or gendered, in particular the Yan Daudu of Kano with a long historical presence much like that of the hijra of South Asia, have in recent years found themselves the butt of violent treatment (Gaudio 2009).

Efforts to clean up aberrant sexual presentation are regarded as important components of the narrowing of the performance of (religiously sanctioned) norms that are helping to preserve masculine superiority and so to ward off the social chaos it is felt would ensue should more egalitarian relations be generally adopted. In this way the new religious establishments have taken over much of the function of the state in keeping society running and so are in line with the current ideology of reducing state responsibilities. This is all the more important because the complementary effect of neoliberal economic relations is to widen the gap between the haves and the have-nots while encouraging the wealthy to renounce obligations towards the welfare of others, through the ideology of individual responsibility. This is counteracted by the newer churches and mosques by placing special onus on their wealthy members to donate a relatively small proportion of their wealth to the impoverished in their congregations, while removing the seemingly endless requirements for even the poor to provide support to all who can claim family ties (Kane 2003; Marshall 2009).

That the end of the pretence that the capitalist system was ever going to produce decent jobs for all has not been accompanied by social collapse is said by many of those with whom I spoke in Kaduna to be due to the preservation of the gender system bolstered by religion. This combination has gone a considerable way to support a social order that depends on men's capacity to retain the 
superior position to which masculinity supposedly entitles them, in large part by controlling the behaviour of other family members. To ensure the maintenance of this order, male household heads who fail to keep control within their own families are threatened with emasculation. In such ways does the gender system support governmentality.

The fourth foundational element of masculinity - bravery/protection - is also reinforced by the new religious institutions, at least in Kaduna, through their demonization of the other religion. It has been not uncommon, particularly when frictions between the two faiths are on the increase, for clerics on both sides to preach hatred in their weekly sermons (Marshall 2009: 230). This was periodically remarked upon during my time in Kaduna and was said to have been a significant element in encouraging congregants to participate in riots, along with pressures related to masculinity, since it was the duty of a 'real man' to provide protection for his own cultural grouping when appropriate, through participating in public acts of violence (Harris 2012b: 228). Finally, to dedicate oneself to fighting the Lord's wars is a crucial element of the newer movements for both religions (Marshall 2009).

\section{Conclusion}

The new forms of Islam and Christianity discussed in this paper arose as responses to the same social and economic challenges. While both seek to purify religion in specific ways, this is not about returning to the past but rather concerns putting into practice ideas corresponding to the needs of contemporary life at a time of disillusionment with the notion of a secular state. Each religious movement offers a promise that under their particular umbrella corruption will vanish and the state will uphold justice and piety. This brings them into competition with one another, particularly in northern Nigeria, encouraging mutual demonization and even physical violence (Larkin and Meyer 2006; Marshall 2009).

However, this is not simply a matter of the material. These establishments feed into local beliefs that ultimate causes reside in the realm of the supernatural and find new ways of harnessing these beliefs into structures in which sin is a matter of individuals taking personal responsibility for their own righteousness rather than depending on the intercession of religious leaders (Kane 2003; Marshall 2009).

The capitalist system is so organised that social stability has come to depend in the first place on the majority of families having access to sustainable, decently paid employment, sufficient to allow them to live secure lives. As neoliberalism has ended the dream that this might someday be attainable in Nigeria, masculinity and religion have come to be crucial resources for sustaining social order not just for the men of Kaduna but for their families too. 
The symbiotic relationship of masculinity and Christianity was made clear in Nigeria by their simultaneous introduction under European missionary regimes. ${ }^{21}$ The influence first of the colonial setting, and more recently of the international networks to which the newer religious establishments belong has further affected the development of masculinity, enforcing modest dress for women, and legitimising their subordinate status.

Today, the capacity appropriately to perform the foundational elements of masculinity has become tightly connected to the precepts of the new religious establishments. They provide a legitimate and ethically founded basis for their congregants to improve their own particular situations by acting independently of traditional social structures, thus boosting not only their finances but also their capacity to provide and so their masculinity. It is this conjunction of masculinity and religion that is helping to preserve social order in Kaduna and ward off the chaos it is feared would arise should it fall apart.

\section{References}

Achebe, Nwando. 2005. Farmers, Traders, Warriors, and Kings: Female Power and Authority in Northern Igboland, 1900-1960. Portsmouth, N.H.: Heinemann.

Adedayo, Adeola Kehinde and Ayuba Yusuf Larry Sanda. 2011. Mystical Powers of Witchcraft among the Gbagyis. Ilorin Journal of Religious Studies 1.1, 77-92.

Adiri, Farouk, Habiba Ismail Ibrahim, Victor Ajayi, Hajaratu Umar Sulayman, Anita Mfuh Yafeh and Clara L. Ejembi. 2010. 'Fertility Behaviour of Men and Women in Three Communities in Kaduna State, Nigeria'. African Journal of Reproductive Health 14.3, 97-105.

Amadiume, Ifi. 1987. Male Daughters and Female Husbands: Gender and Sex in an African Society. London: Zed.

Andersson, Ulrika. 2002. Working with Spirits among Muslim Hausa in Nigeria: A Study of Bori in Jos. Working Papers in Cultural Anthropology 11. Uppsala University.

Andræ, G. and B. Beckman. 1998. Union Power in the Nigerian Textile Industry: Labour Regime and Adjustment. Uppsala: Nordiska Afrikainstitutet.

Asad, Talal. 2001. 'Reading a Modern Classic: W. C. Smith's "The Meaning and End of Religion"'. History of Religions 40.3, 205-222.

Asad, Talal. 1983. 'Anthropological Conceptions of Religion: Reflections on Geertz'. Man, New Series, 18.2, 237-259.

Bakare-Yusuf, Bibi. 2011. 'Nudity and Morality: Legislating Women's Bodies and Dress in Nigeria'. In Sylvia Tamale (ed.), African Sexualities: a Reader. Oxford: Pambazuka Press, 116-129.

Ben Amara, Ramzi. 2011. The Izala Movement in Nigeria: Its Split, Relationship to Sufis and Perception of Sharīa Re-Implementation. PhD thesis, Bayreuth International Graduate School of African Studies, Universität Bayreuth. https://epub.uni-bayreuth.de/101/1/BenAmaraDiss.pdf [Accessed 15.6.2016]. 
Bobboyi, H. and A.M. Yakubu. 2005. Peacebuilding and Conflict Resolution in Northern Nigeria. Kaduna: Arewa House.

Bourdieu, Pierre. 2001. Masculine Domination (Richard Nice trans.). Stanford, CA: Stanford University Press.

Bununu, Y.A., A.N.M. Ludin and Nafisa Hosni. 2015. 'City Profile: Kaduna'. Cities 49, 53-65.

Carrier, Joseph M. and Stephen O. Murray. 1998. 'Woman-Woman Marriage in Africa'. In Stephen O. Murray and Will Roscoe (eds.) Boy-wives and female husbands: studies in African homosexualities. New York: St. Martin's Press, 255-266.

Coles, Catherine. 1991. 'Hausa Women's Work in a Declining Urban Economy: Kaduna, Nigeria, 1980-1985'. In Catherine Coles and Beverley Mack (eds.) Hausa Women in the Twentieth Century. Madison, WI: The University of Wisconsin Press, 163-191.

Danfulani, Umar Habila Dadem. 1999. 'Factors Contributing to the Survival of the Bori Cult in Northern Nigeria'. Numen 46, 412-447.

Falola, Toyin. 1998. Violence in Nigeria: The Crisis of Religious Politics and Secular Ideologies.

Rochester, NY: University of Rochester Press.

Falola, Toyin and Matthew Heaton. 2008. A History of Nigeria. Cambridge: Cambridge University Press.

Foucault, Michel. 1990. A History of Sexuality: an Introduction (Robert Hurley, trans.). London: Penguin.

Gandu , Y. 2011. 'Historical and Contemporary Basis for Sectarian Residential Settlement Patterns in Kaduna Metropolis of Northern Nigeria'. Mawazo: The Journal of the College of Humanities and Social Sciences, Makerere University 10.3, 72-91.

https://chuss.mak.ac.ug/downloads/mawazo/NEW_MAWAZO_EDITION_8_SEP_2011.pdf [Accessed 15.6.2016].

Gaudio, Rudolf Pell. 2009. Allah Made us: Sexual Outlaws in an Islamic African City. Oxford: Wiley-Blackwell.

Hansen, Holger Bernt. 1984. Mission, Church and State in a Colonial Setting. London: Heinemann.

Harris, Colette. 2013. 'Violence in a Religiously Divided City: Kaduna, Nigeria - from the Shari'a Riots of 2000 to the Post-Election Clashes of 2011'. Space and Polity 17.3, 284-299.

Harris, Colette. 2012a. 'Gender-Age Systems and Social Change: A Haugaardian Power Analysis Based on Research from Northern Uganda'. Journal of Political Power 5.3, 475-492.

Harris, Colette. 2012b. 'Masculinities and Religion in Kaduna, Nigeria: A Struggle for Continuity at a Time of Change'. Religion and Gender 2.2, 207-230.

Harris, Colette. 2011. 'Deconstructing Masculinities in Kaduna, Nigeria'. In Alp Biricik and Jeff Hearn (eds.), GEXcel Work in Progress Report Volume XV: Proceedings GEXcel Theme 9, 241-252. http://liu.diva-portal.org/smash/get/diva2:550947/FULLTEXT01.pdf [Accessed 15.6.2016].

Harris, Colette. 2006. 'Doing Development with Men: Some Reflections on a Case Study from Mali'. Rosalind Eyben, Colette Harris, and Jethro Pettit (eds.) IDS Bulletin 37.6, 47-56.

Harris, Colette. 2004. Control and Subversion: Gender Relations in Tajikistan. London: Pluto. 
Hill, Jonathan N. C. 2010. Sufism in Northern Nigeria: Force for Counter-Radicalization? Carlisle, PA: Strategic Studies Institute.

http://www.strategicstudiesinstitute.army.mil/pdffiles/pub989.pdf [Accessed 15.6.2016].

Imam, Ayesha. 1994. 'Politics, Islam, and Women in Kano, Northern Nigeria'. In Valentine M. Moghadam (ed.), Identity Politics and Women: Cultural Reassertions and Feminisms in International Perspective. Boulder: Westview, 123-144.

Jackson, Cecile. 1985. Women's Roles and Gender Differences in Development: The Kano River Project. West Hartford, CT: Kumarian Press. Http://Ufdc.Ufl.Edu//UF00086611/00001 [Accessed 15.6.2016].

Kane, Ousmane. 2003. Muslim Modernity in Postcolonial Nigeria: A Study of the Society for the Removal of Innovation and Reinstatement of Tradition. Leiden: Brill.

Kazah-Toure, Toure. 2002. Ethno-Religious Conflicts in Kaduna State. Kaduna: Human Rights Monitor.

Kraxberger, Brennan. 2005. 'Strangers, Indigenes and Settlers: Contested Geographies of Citizenship In Nigeria'. Space and Polity 9.1, 9-27.

Kukah, Matthew Hassan. 1993. Religion, Politics and Power in Northern Nigeria. Ibadan: Spectrum Books.

Labode, Modupe. 1993. 'From Heathen Kraal to Christian Home: Anglican Mission Education and African Christian Girls, 1850-1900'. In Fiona Bowie, Deborah Kirkwood and Shirley Ardener (eds.), Women and Missions: Past and Present. Providence, RI: Berg, 126-144.

Larkin, Brian and Birgit Meyer. 2006. 'Pentecostalism, Islam and Culture: New Religious Movements in West Africa'. In Emmanuel Akyeampong (ed.) Themes in West Africa's History. Oxford: James Currey, 286-312.

Lindsay, Lisa A. 2007. 'Working With Gender: The Emergence of the "Male Breadwinner" in Colonial Southwestern Nigeria'. In Catherine M. Cole, Takyiwaa Manuh, and Stephan F. Miescher (eds.) Africa after Gender. Bloomington, IN: Indiana University Press, 241-252.

Loimeier, Roman. 1997. Islamic Reform and Political Change in Northern Nigeria. Evanston, IL: Northwestern Press.

Long, Scott. 2003. 'Before the Law: Criminalizing Sexual Conduct in Colonial and Post-Colonial Southern African Societies'. In More Than a Name: State-Sponsored Homophobia and its Consequences in Southern Africa. Human Rights Watch, 256-297. http://www.hrw.org/sites/default/files/reports/safriglhrc0303.pdf [Accessed 15.6.2016].

Mack, Beverly B. and Jean Boyd. 2000. One Woman's Jihad: Nan Asma'u, Scholar and Scribe. Bloomington, IN: Indiana University Press.

Marshall, Ruth. 2009. Political Spiritualities: The Pentecostal Revolution in Nigeria. Chicago: University of Chicago Press.

Maxwell, David. 1998. "'Delivered from the Spirit of Poverty?": Pentecostalism, Prosperity and Modernity in Zimbabwe'. Journal of Religion in Africa 28.3, 350-373.

Mbiti, John S. 1969. African Religions and Philosophy. London: Heinemann.

Mbiti, John, S. 1970. Concepts of God in Africa. London: Praeger. 
Meagher, Kate. 2013. 'Informality, Religious Conflict, and Governance in Northern Nigeria: Economic Inclusion in Divided Societies'. African Studies Review 56.3, 209-234.

Nasir, Jamila. 2007. 'Sharia Implementation and Female Muslims in Nigeria's Sharia States'. In Philip Ostien (compiled and ed.), Sharia Implementation in Northern Nigeria, 1999-2006: A Sourcebook, Volume III. Ibadan, Nigeria: Spectrum Books, 76-118.

Nzegwu, Nkiru Uwechia. 2006. Family Matters: Feminist Concepts in African Philosophy of Culture. Albany: State University of New York Press.

Ojo, Matthew (2007) 'Pentecostal Movements, Islam and the Contest for Public Space in Northern Nigeria'. Islam and Christian-Muslim Relations 18.2, 175-188.

Oyěwùmí, Oyèrónké. 1997. The Invention of Women: Making an African Sense of Western Gender Discourses. Minneapolis: University of Minnesota Press.

p'Bitek, Okot. 1971. The Religion of the Central Luo. Kampala: East African Literature Bureau.

Peel, J. D. Y. 2000. Religious Encounter and the Making of the Yoruba. Bloomington: University of Indiana Press.

Peel, J. D. Y. 1993. 'An Africanist Revisits Magic and the Millennium'. In Eileen Barker, James A. Beck Ford, and Karel Dobbelaere (eds.), Secularization, Rationalism and Sectarianism. Oxford: Clarendon Press, 81-100.

Pew Forum on Religion \& Public Life. 2010. Islam and Christianity in Sub-Saharan Africa. Washington, DC: Pew Research Center. http://www.pewforum.org/2010/04/15/executive-summaryislam-and-christianity-in-sub-saharan-africa/ [Accessed 15.6.2016].

Prevost, Elizabeth E. 2010. The Communion of Women: Missions and Gender in Colonial Africa and the British Metropole. Oxford: Oxford University Press.

Ratele, Kopano. 2011. 'Male Sexualities and Masculinities'. In Sylvia Tamale (ed.) African Sexualities: a Reader. Oxford: Pambazuka Press, 399-419.

Renne, Elisha P. 2012. 'Educating Muslim Women and the Izala Movement in Zaria City, Nigeria'. Islamic Africa 3.1, 55-86.

Rogers, Barbara. 1980. The Domestication of Women: Discrimination in Developing Societies, London: Kogan Page.

Rose, Sonya O. 1986 '"Gender At Work": Sex, Class and Industrial Capitalism'. History Workshop 21.1, 113-131.

Saidi, Christine (2010) Women's Authority and Society in Early East-Central Africa. Rochester, NY: University of Rochester Press.

Salamone, Frank. 2007. 'Hausa Concepts of Masculinity and the "Yan Daudu". Journal of Men, Masculinities and Spirituality 1.1, 45-54.

Shaw, Rosalind (2002) Memories of the Slave Trade: Ritual and the Historical Imagination in Sierra Leone. Chicago: Chicago University Press.

Sinha, Mrinalini. 1995. Colonial Masculinity: The Manly Englishman and the Effeminate Bengali. Manchester: Manchester University Press.

Tamale, Sylvia. 2013. 'Confronting the Politics of Nonconforming Sexualities in Africa'. African Studies Review 56.2, 31-45. 
Teal, Francis. 2014. Employment Creation, Poverty and the Structure of the Job Market in Nigeria. CSAE Working Paper WPS/2014-18, University of Oxford. http://www.Csae.ox.ac.uk/Workingpapers/Pdfs/Csae-Wps-2014-18.Pdf [Accessed 15.6.2016].

Watts, Michael. 1990. 'The Shock of Modernity: Money, Protest and Fast Capitalism in an Industrialising Society'. In Allan Pred and Michal Watts (eds.), Reworking Modernity: Capitalism and Symbolic Discontent. New Brunswick, N.J.: Rutgers University Press, 21-64.

\section{Notes}

${ }^{1}$ Thanks to Dorothea Schulz, Marloes Jansen, and two anonymous reviewers for their comments on an earlier draft.

${ }^{2}$ Kaduna city is the capital of the state of the same name. In this paper, Kaduna without qualification will be used to refer to the city.

3 'A bill for an Act to prohibit and punish public nudity, sexual intimidation and other related offences in Nigeria', introduced in the senate in 2007 but never passed, is popularly known as the nudity bill (Bakare-Yusuf 2011: 117).

${ }^{4}$ From 2007-2008 the projects were sponsored by the DfID-funded Citizenship Development Research Centre run by the Institute of Development Studies, Sussex and from 2008-2011 by the AHRC/ESRC-funded Religion and Society Programme run by the University of Lancaster.

${ }^{5}$ For more details on project participants see Harris (2013: 285).

${ }^{6}$ For more details on Kaduna city see Harris (2013).

${ }^{7}$ Participants in a round table chaired by Mohammadu Buhari, now President of Nigeria, alleged politicians gave unemployed youths money, weapons and drugs to organise sectarian violence (Bobboyi and Yakubu 2005: 211ff).

${ }^{8}$ Now expanded as Evangelical Church Winning All.

${ }^{9}$ Islamism principally focuses on founding a religiously-based state, such as Iran, while reform Islam emphasises individual reformation through personal interpretation of the scriptures (Kane 2003).

${ }^{10}$ Its full Hausa name is Jama'at izalat al bid a wa iqamat al-sunna.

${ }^{11}$ Sunna comprises the Qur'an, Hadith and other teachings of the Prophet (Kane 2003).

${ }^{12}$ The Society for the Victory of Islam.

${ }^{13}$ Hereby providing a rationale for racism.

${ }^{14}$ From gender traits by Christian youths in Kaduna.

${ }^{15}$ Gambling and alcohol consumption are other ways not addressed in the present paper. Having multiple sex partners is another but in Kaduna the youths I worked with claimed it was mainly married men who had multiple relationships.

${ }^{16}$ https://knoema.com/IMFWEO2016Apr/imf-world-economic-outlook-weo-april-2016 [Accessed 15.6.2016].

${ }^{17}$ Aligning contemporary understanding of Islam with capitalist ideology.

${ }^{18}$ Personal communication from Maji Peterx of the NGO Carefronting, reporting on group discussions with men on their roles in family life in conjunction with one of his NGO's projects.

${ }^{19}$ Further evidence regarding this propensity, albeit in a rural part of Kaduna State, can be found in Adiri et al (2010).

${ }^{20}$ The giving of alms to the poor. 
${ }^{21}$ This would seem also to have considerably influenced the development of masculinity among Nigerian Muslims but more research is needed into how Islam affected male-female behaviour patterns in pre-colonial, pre-Christian Sub-Saharan Africa. 